good progress was made, both in the development of the exhibited collections and in the less spectacular research conducted in the laboratories. That this work should now have been brought almost to a stop is regrettable, if inevitable. The announcement recently made that certain galleries are to be reopened to the public, and that special exhibits of current interest are being arranged, will be widely welcomed.

\section{Biology in Schools}

THE latest report of the Joint Committee of the Four Secondary Associations shows useful and, indeed, necessary work for education in the way of criticism, protest and suggestion. Complacency about the success of evacuation is now being reduced. Authorities who commandeer schools for officials and leave school buildings in a defective state have much to answer for. Such unwise economy is strange, after reckless expenditure elsewhere. A subsidiary subject syllabus is printed which a sub-committee of biologists has suggested for a London Higher School Certificate, since separate syllabuses for botany and zoology are regarded as unsatisfactory. This scheme for biology includes six important subjects, from histology to heredity and ecology, though the last-named is reduced to the study of fauna and flora in a restricted area. A practical examination and a written paper, each for three hours, are proposed, but the former, if ill-done, will not mean failure in the subject as a whole. The wide ground is well covered but, as the average teaching time for the whole of the syllabus, including practical work, is three hours a week, is there not too much to get through ? Ambitious programmes tend to produce shallow knowledge which is soon lost.

\section{Cave Man in Colorado}

Excavation of a cave near Durango, Colorado, it is anticipated, may afford evidence for an approximate early dating of basket-maker culture in the southwestern States. The investigation was carried out on behalf of the Carnegie Institution of Washington by Earl H. Morris. Evidence of occupation, according to a report circulated by Science Service of Washington, D.C., was found below three feet of accumulated debris. There were indications that the inhabitants had lived in one-room structures, with mud-coated floors and fire-pits, though how these constructions were built was not detected. Corn and pumpkins were grown, but the principal mode of subsistence apparently was by hunting.

The most significant find, however, consisted of charcoal, from which tree-ring sequences have been constructed each covering a period of at least one hundred years. These are not only independent of one another, but also of any known Indian tree-ring datings. As these last have now been carried back to about A.D. 150, unless, as Dr. A. V. Kidder has suggested, conditions in this area were entirely different from the normal for northern Colorado, this constitutes valid evidence for Basket-maker occupation of the cave at not less than approximately two thousand years ago.

\section{A Preparation for the Control of Bleeding}

A FAT-SOLUBLE vitamin, known as vitamin $\mathrm{K}$, is indirectly concerned with blood coagulation, will reduce the clotting time of blood in cases of prothrombin deficiency, and will check certain forms of hæmorrhage, such as occur in obstructive jaundice and occasionally in new-born babies. Vitamin $\mathrm{K}$ is found naturally in alfalfa and hog's liver fat, it has been isolated and its chemical composition determined. Several related but simpler compounds are known possessing a physiological action similar to the natural vitamin $K$, and one of these-a methylnaphthaquinone-has been introduced for use in medicine by Glaxo Laboratories, Ltd., Greenford, Middlesex, under the name "Kapilon". Kapilon has been found to be a valuable agent for reducing bleeding in obstructive jaundice and in neo-natal hæmorrhage.

\section{Institution of Electrical Engineers : Scholarships}

THE following scholarships are open for award by the Institution of Electrical Engineers during 1940 : Duddell Scholarship (value $\$ 150$ per annum, tenable for three years), open to British subjects less than nineteen years of age on July 1, for a whole-time day course in electrical engineering ; Ferranti Scholarship (value $£ 250$ per annum, tenable for two years), open to British subjects less than twenty-six years of age on July 1, who are students or graduates of the Institution, for whole-time research or postgraduate work of an electrical engineering nature; Swan Memorial Scholarship (value $£ 120$, for one year), open to British subjects less than twentyseven years of age on July 1, for whole-time research or post-graduate work of an electrical engineering nature; Silvanus Thompson Scholarship (value $£ 100$ per annum and tuition fees, tenable for two years), for works' employees who are the sons of parents of limited means, open to British subjects less than twenty-two years of age on July 1, for a whole-time day course in electrical engineering at an approved university or technical college; William Beedie Esson Scholarship (value $£ 120$ per annum, tenable for two years, renewable in approved cases for a third year), for works' employees who are the sons of parents of limited means, open to British subjects less than twenty-two years of age on July 1, for a whole-time day course in electrical engineering at an approved university or technical college. Further information can be obtained from the Secretary, Institution of Electrical Engineers, Savoy Place, London, W.C.2.

\section{Royal Society of Edinburgh: New Fellows}

THE following have been elected fellows of the Royal Society of Edinburgh : Mr. E. B. Ball, president of the Institution of Mechanical Engineers; Mr. J. Bowman, City water engineer, Edinburgh; Mr. B. S. Bramwell, advocate, London; Mr. J. Brough, lecturer in vertebrate zoology, University of Edinburgh; Dr. A. F. Buchan, teacher of mathematics, James Gillespie's School, Edinburgh ; Mr. J. M. Caie, deputy secretary, Department of Agriculture for 
Scotland; Mr. J. Cameron, formerly head of the Pharmaceutical Department, Peiping Union Medical College ; Prof. J. W. Cook, Department of Chemistry, University of Glasgow ; Dr. J. Coutts, lecturer in pharmaceutics and demonstrator in practical pharmacy, St. Bartholomew's Hospital Medical College, London; Mr. Satchidinanda Datta, veterinary research officer, Imperial Veterinary Research Institute, Calcutta; Dr. T. Elder Dickson, art master, George Watson's Ladies College, Edinburgh; Dr. A. T. J. Dollar, assistant in the Department of Geology, University of Glasgow ; Dr. H. I. Drever, assistant in the Department of Geology, University of St. Andrews; Mr. W. McC. Harrowes, medical director, New Saughton Hall Private Mental Hospital, Polton, Midlothian; Mr. T. Hart, collector of the Trades House of Glasgow; Prof. C. F. W. Illingworth, Department of Surgery, University of Glasgow ; Mr. J. G. Kyd, registrar-general for Scotland; Mr. P. R. Laird, secretary to Department of Agriculture for Scotland; Dr. Robert MeAdam, lecturer in mining and surveying, Heriot-Watt College, Edinburgh; Dr. J. A. Macdonald, lecturer in botany, University of St. Andrews ; Dr. A. E. W. McLachlan, clinical medical officer, Newcastle General Hospital, Newcastle-upon-Tyne; Dr. A. MacNiven, physician superintendent, Royal Mental Hospital, Glasgow ; Prof. G. F. Marrian, Department of Chemistry in relation to Medicine, University of Edinburgh ; Dr. E. R. A. Merewether, H.M. medical inspector of factories, Birmingham; Mr. R. M. Neill, senior lecturer in zoology, University of Aberdeen; Dr. H. B. Nisbet, lecturer in chemistry, Heriot-Watt College, Edinburgh ; Mr. J. S. C. Reid, solicitorgeneral for Scotland; Mr. H. Riley, founder and headmaster of Strathallan School, Forgandenny, Perthshire; Mr. J. Thomson, distiller, London; Dr. H. M. Traquair, president of the Royal College of Surgeons of Edinburgh, lecturer on diseases of the eye, University of Edinburgh.

\section{Announcements}

THE council of the Royal Society of Edinburgh has awarded the Keith Prize for the period 1937-39 to Prof. F. A. E. Crew, for his papers and joint papers in the Proceedings of the Society within the period of the award, and in recognition of his valuable contributions to animal genetics ; and the Neill Prize to Mr. James Wright, for his important paper on "The Scottish Carboniferous Crinoidea", published in the Transactions of the Society within the period of the award.

THE Senatus of the University of Edinburgh has awarded the Cameron Prize to Prof. E. C. Dodds, Courtauld professor of biochemistry in the University of London, for his work on synthetic œestrogens.

THe Masters Memorial Lectures of the Royal Horticultural Society will be delivered in the lecture room of the Society's New Hall in Greycoat Street, Westminster, on April 2 and 16, at 3 p.m., by Prof. F. E. Weiss, on "Graft Hybrids and Chimaeras".
Prof. Max Born, Tait professor of natural philosophy in the University of Edinburgh, will give the distinguished visitor's address before the Royal College of Science Mathematical and Physical Society at the College on March 11 at 5.15. Prof. Born's address will be entitled "On Melting".

Mr. T. T. PAterson, curator of the University Museum of Archæology and Ethnology, Cambridge, will deliver the Swiney lectures on geology in the rooms of the Linnean Society on Fridays and Mondays, at 3 p.m., from March 29 until May 10 (April 19 excepted). The subject of the lectures, to which admission is free, will be "Geology and Early Man".

The Committee on the Chemistry of Proteins of the Division of Chemistry and Chemical Technology of the National Research Council has been granted 3,600 dollars by Mr. Eli Lilly of Indianapolis, for the establishment of a National Research Council fellowship in protein chemistry. The fellowship has been awarded to Dr. I. Fankuchen, who will carry on X-ray research on proteins in the laboratory of Prof. B. E. Warren at the Massachusetts Institute of Technology.

The twelfth International Congress of Psychology, which was planned to take place at Edinburgh in July 1940, has been postponed, though not abandoned. The invitation of the City and University of Edinburgh is not withdrawn, and the Local Organization Committee hopes that the Congress may still meet in Edinburgh when circumstances permit the continuation and completion of the preparations.

THE annual meeting of the Swiss Society of Internal Medicine will be held in Bern during May 18-19, when the following subjects will be discussed: the chemistry of vitamins and some enzymes, introduced by Prof. P. Karrer of Zurich ; the hypovitaminoses in medical practice, introduced by Prof. Bickel of Geneva. Further information can be obtained from the president, Dr. Otto Roth, Kantonspital, Winterthur.

AN Argentine Society of Social Medicine has recently been founded at Buenos Aires.

A monument has been erected at Chateauroux, France, of Stanislas Limousine, the chemist, who invented wafers for unpleasant drugs and pipettes for counting drops, introduced coloured bottles for poisons, organized the first public laboratory, and first injected quinine hypodermically.

ACCORDING to an investigation carried out in Calcutta, more than 96 per cent of 887 maternal deaths were due to an avoidable factor. Puerperal sepsis accounted for 32 per cent, eclampsia for 18 per cent, hæmorrhage for 11 per cent, anæmia for 24 per cent, and septic abortion for 5 per cent. The chief cause of death from diseases associated with child-bearing was pulmonary tuberculosis, which accounted for 40 per cent. 